British firms, and at least a few of them match American offers.

On a somewhat higher and more specialized level, a new Scientists Appointment Service has been established by five British scientific institutions. It will attempt to register British scientists who are going to the United States under postdoctoral fellowships but who are intending to return to England to work. This information will be made available to any interested British firm and may ease some of the problems of transatlantic recruiting. At present, while British scientists in American universities are actively pursued by American firms, they only hear about British openings months after the posts have been filled. Since most of the scientists registered with SAS have good honours degrees and usually PhDs as well, they would have no problem finding jobs if they were in England; instead, the problems seem to lie in communication and education.

Education is needed for both potential employees and employers; the Royal Institute of Chemistry, which started a more limited programme 18 months ago, has found that many researchers look on industrial work as somehow inferior and will consider offers only as a last resort. On the other hand, many firms are suspicious of scientists returning from America, believing they will want too much money. When the Chemical Industries Association, at the request of the Royal Institute of Chemistry, sent out details of the original registering scheme to approximately 600 members, only about 50 companies were interested enough to reply.

It was this poor response from industry, in fact, that led the Royal Institute of Chemistry to approach four others-the Institute of Physies and the Physical Society, the Institute of Biology, the Institute of Mathematics and Its Applications, and the Institution of Metallurgists--in order to reach as many scientists and companies as possible. The Ministry of Technology also agreed to support the project with a $£ 10,000$ grant for the first year. After the inertia and lack of interest shown by the British companies approached by the Chemical Industries Association last year, the enlarged appointments service intends to spend most of its funds on advertising and promotional ideas to attract more firms. The service charges nothing until a firm has actually employed a scientist through its register; then the fee is $£ 100$.

\section{Progress of Nations}

The Organization for Economic Cooperation and Development (OECD) has issued the annual accounts of its member countries from 1957 to 1966 (National Accounts Statistics, OECD, $£ 1 \cdot 875 / \$ 5 \cdot 5)$. The accounts would be even more interesting if accompanied by a chairman's report, but the OECD has perhaps wisely eschewed comment; the invidious comparisons are explicit enough in the figures themselves.

Japan has more than doubled her gross national product (GNP) since 1958, although her GNP per capita is still low compared with European countries (see table). Britain's GNP has risen by less than a third over the period, a rate of increase lower than any OECD country including Turkey. Although the percentage increase of GNP in the United States is not spectacular, the increase in absolute terms dwarfs
GROSS NATIONAL PRODUCT (MARKET PRICES) OF OECD COUNTRIES IN 1966

\begin{tabular}{|c|c|c|c|c|}
\hline & $\begin{array}{l}\text { GNP in } \\
\text { US } \\
\text { \$billion } \\
\text { (current } \\
\text { prices) }\end{array}$ & $\begin{array}{c}\text { GNP at } \\
1958 \\
\text { prices } \\
\text { (Index: } \\
1958 \\
=100 \text { ) }\end{array}$ & $\begin{array}{c}\text { GNP } \\
\text { per } \\
\text { capita } \\
\text { US } \$ \\
\text { (current } \\
\text { prices) }\end{array}$ & $\begin{array}{c}\text { GNP per } \\
\text { capita at } \\
\text { 1958 prices } \\
\text { (Index: } \\
1958 \\
=100)\end{array}$ \\
\hline $\begin{array}{l}\text { Canada } \\
\text { United States } \\
\text { Japan }\end{array}$ & $\begin{array}{c}53 \cdot 5 \\
756 \cdot 49 \\
96 \cdot 42\end{array}$ & $\begin{array}{l}147 \\
146 \\
220\end{array}$ & $\begin{array}{r}2,670 \\
3,840 \\
970\end{array}$ & $\begin{array}{l}125 \\
129 \\
203\end{array}$ \\
\hline $\begin{array}{l}\text { France } \\
\text { Germany } \\
\text { United Kingdom }\end{array}$ & $\begin{array}{l}102 \cdot 11 \\
119 \cdot 62 \\
105 \cdot 05\end{array}$ & $\begin{array}{l}151 \\
152 \\
131\end{array}$ & $\begin{array}{l}2,070 \\
2,010 \\
1,910\end{array}$ & $\begin{array}{l}136 \\
138 \\
124\end{array}$ \\
\hline $\begin{array}{l}\text { Austria } \\
\text { Italy } \\
\text { Switzerland }\end{array}$ & $\begin{array}{l}10 \cdot 06 \\
61 \cdot 49 \\
14 \cdot 90\end{array}$ & $\begin{array}{l}142 \\
154 \\
151\end{array}$ & $\begin{array}{l}1,380 \\
1,180 \\
2,480\end{array}$ & $\begin{array}{l}136 \\
145 \\
131\end{array}$ \\
\hline $\begin{array}{l}\text { Belgium } \\
\text { Netherlands } \\
\text { Turkey }\end{array}$ & $\begin{array}{r}18 \cdot 22 \\
20 \cdot 77 \\
9 \cdot 42\end{array}$ & $\begin{array}{l}143 \\
151 \\
146\end{array}$ & $\begin{array}{r}1,910 \\
1,670 \\
290\end{array}$ & $\begin{array}{l}135 \\
136 \\
119\end{array}$ \\
\hline $\begin{array}{l}\text { Denmark } \\
\text { Norway } \\
\text { Sweden }\end{array}$ & $\begin{array}{r}11 \cdot 14 \\
7 \cdot 59 \\
21 \cdot 33\end{array}$ & $\begin{array}{l}150 \\
147 \\
143\end{array}$ & $\begin{array}{l}2,320 \\
2,020 \\
2,730\end{array}$ & $\begin{array}{l}141 \\
138 \\
136\end{array}$ \\
\hline $\begin{array}{l}\text { OECD total } \\
\text { OECD Europe } \\
\text { EEC }\end{array}$ & $\begin{array}{r}1,447 \cdot 53 \\
541 \cdot 11 \\
322 \cdot 91\end{array}$ & $\begin{array}{l}149 \\
147 \\
151\end{array}$ & $\begin{array}{l}2,160 \\
1,530 \\
1,760\end{array}$ & $\begin{array}{l}136 \\
135 \\
139\end{array}$ \\
\hline
\end{tabular}

that of any other country. Between 1965 and 1966 the US GNP rose by $\$ 61$ billion, an increment equal to the Italian GNP in 1966.

Italy devotes a smaller part of her GNP to research and development than almost any European country $(0 \cdot 3$ per cent in 1963 as against $2 \cdot 3$ per cent for the UK and 3.4 per cent for the USA) and her bill for patents and licences is correspondingly great; despite this, her GNP has risen faster than any OECD country but Japan. Rewards for virtue do not seem to obey the usual indicators of technological development, which suggests that the indicators are too crude or too incomplete.

The national accounts for each country are displayed both in absolute form and in index form with 1958 as a base. In Britain the components of GNP have risen at a rather uniform rate-consumer expenditure to 128 $(1958=100)$, government expenditure to 122 , exports to 132 and imports to 139 -despite the fact that capital investment has risen 61 per cent since 1958. Italy, with a capital investment increase of only 45 per cent, has raised consumer expenditure to 152 , government expenditure to 140 and exports and imports to 298 and 275, respectively, over the same period. Capital investment increases for other countries have been United States 146, Japan 284, France 175 and Germany 189.

Standard of living as judged by the per capita GNP (though this ignores the effect of taxes and the social services) is more than twice as high in the US as in Europe as a whole (see table). Sweden, however, comes second in this league table, followed closely by Canada and Switzerland.

\section{Coordinating Cancer Research}

A NEW organization-the British Cancer Council-has been set up under the presidency of Professor Sir John Bruce of Edinburgh to act as an advisory body at national and international levels, to promote the inter- 